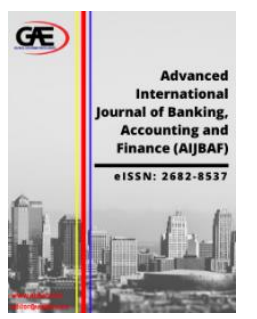

\author{
ADVANCED INTERNATIONAL JOURNAL OF \\ BANKING, ACCOUNTING AND FINANCE \\ (AIJBAF) \\ www.aijbaf.com
}

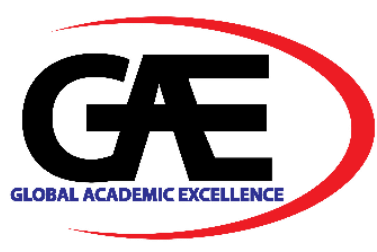

\title{
SALES TAX COMPLIANCE AND ITS DETERMINANTS IN MALAYSIA
}

Tee Leap Sing ${ }^{1}$, Zainol Bidin ${ }^{2}$

1 Tunku Puteri Intan Safinaz School of Accountancy, Universiti Utara Malaysia, Malaysia

Email: wendytls68@gmail.com

2 Tunku Puteri Intan Safinaz School of Accountancy, Universiti Utara Malaysia, Malaysia

Email: b.zainol@uum.edu.my

\section{Article Info:}

\section{Article history:}

Received date:04.10.2020

Revised date: 15.10 .2020

Accepted date: 30.10 .2020

Published date: 01.12.2020

\section{To cite this document:}

Tee, L. S., \& Bidin, Z. (2020). Sales Tax Compliance and Its Determinants in Malaysia. Advanced International Journal of Banking, Accounting, and Finance, 2 (5), 01-20.

DOI: 10.35631/AIJBAF.25001.

This work is licensed under $\mathrm{CC}$ BY 4.0

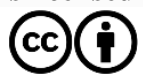

\section{Abstract:}

Tax compliance behaviour has been addressed as a continuous serious concern globally. However, empirical research on sales tax compliance in Malaysia is still scarce. The present study can be considered a first attempt that was conducted in the context of sales tax version 2.0 for sales tax compliance in Malaysia. The main objective of this study was to investigate the determinants of sales tax compliance behaviour among Small and Medium Enterprises (SMEs) in Malaysia. The studies used the Fischer model as a basic model with the inclusion of socio-psychological factors (tax complexity, peer influence, tax fairness, tax knowledge, service quality, and compliance cost) and economic factors (tax complexity) with sales tax compliance. As a new contribution to tax compliance knowledge, the relationship between tax compliance behaviour and its determinants was also examined. Using the samples collected from employees who are working in SMEs under the manufacturing sector, findings show that tax complexity, tax fairness, peer influence, and tax knowledge have significant influences on compliance behavior. Meanwhile tax law and enforcement, service quality and compliance cost variable on tax compliance were non-significant. This study concluded with the theoretical and practical implications for the tax authority and the government of Malaysia.

Keywords:

Tax Complexity, Tax Fairness, Peer Influence, Tax Knowledge, SST 2.0 


\section{Introduction}

Many countries rely heavily on taxation as a source of government revenue. Malaysia's main sources of income are direct and indirect taxation. Collecting tax revenue is essential for the government to finance its operating and development expenditures (Hartner et al., 2008 About $50 \%$ of the total revenue collected is generated from corporate income tax and various types of indirect taxes such as custom and import duties, goods and services tax (GST), sales and service tax (SST) and et cetera. In 2018, direct taxes and indirect taxes added 133.474 billion (76.4 percent) and RM41.23 billion (23.6 percent) to government revenue (Malaysian Federal Government Treasury Annual Economic Report, 2017-2018), representing 73.88\% of Malaysian government revenue. This study focuses on indirect taxation, namely the sales and service tax ("SST") as a source of government revenue. SST is imposed when a service or product is delivered to its final consumer. In September 2018, the Ministry of Finance announced that the Goods and Services Tax (GST) was abolished and would again be replaced by the Sales and Services Tax (SST 2.0). A total of 94,783 companies came under list of the Sales and Service Tax as at 14 September 2018, including 56,918 service providers and 37,865 manufacturers. The revenue from SST, which was initially estimated at RM22 billion in the 2019 budget, was revised upwards to RM26.8 billion in 2019 in anticipation of increased sales tax revenue at RM15.5 billion and service tax at RM11.3 billion (Ministry of Finance, Fiscal Outlook and Federal Government Revenue Estimates 2020).

Despite the various fiscal measures undertaken by the Malaysian government to increase domestic revenue collection, the annual reports demonstrated a sharp rise in tax noncompliance, specifically with the Goods and Service Tax (RMCD Annual Report, 2016). Tax non-compliance, as mentioned earlier, could have long-term negative repercussions on financing the growth and development of the country. Judging from past experience with GST implementation, it is anticipated that tax non-compliance with the newly reinvigorated SST is likely to occur as businesses will try as much as to avoid paying tax. Hence, it is important for RMCD to tackle this issue upfront to minimize the incidences of tax evasion. However, since the sales tax was just newly reintroduced and businesses are required to file first sales and service tax returns by or before November 2018, data on sales tax compliance from SMEs are not yet available. To elucidate on the risk of non-compliance, this research study aims to examine sales tax compliance behaviour. Nura, Abdul-Jabbar \& Ibrahim (2017) asserted that sales tax compliance is referred to as conformity to all policies and regulations including declaring real and accurate revenue received, actual selling liabilities liability, as well as prompt and proper collection of all required tax returns. Therefore this study is set to investigate the factors influencing tax compliance behavior among SME in Malaysia by incorporating tax complexity, tax fairness, peer influence, tax law enforcement, tax knowledge, service quality and compliance cost in the sales tax compliance model, particularly in determining the extent to which group of manufacturers fully meet their legal tax obligations. Further this study will identify the perception of fairness regarding the sales tax system, the degree of support from business associates also determine the behavioural of taxpayers. Also, there is lack of empirical studies specifically in investigating the determinants of sales tax 2.0 compliance among SMEs in Malaysia. The identification of factors influencing the behavioural compliance of taxpayers is crucial because taxpayers could be influenced and nurtured to engage in sales tax compliance activities over time. 
The present study attempts to investigate the taxpayers on tax compliance behaviour in the era of sales tax 2.0. Business operators must have sufficient tax knowledge to ensure tax compliance with the sales tax by knowing when they are required to register under the Sales Tax Act 2018, to understand the determination of the sales value of taxable goods (Sales Tax Regulation 2018). By understanding whether the person is exempted from payment of sales tax under Schedule A, B \& C. Taxpayers must be advised of how to apply for an exemption under Schedule A, B and C, along with a list of forms and details related to the local purchase or importation of raw materials, packaging materials, manufacturing aids and components exempted from sales tax payments. On 22 April 2019, RMCD announced that a company which has been approved with sales tax exemption under the Order is required to prepare the exemption reports. The completed report should be kept and made readily available for submission upon request by sales tax officer or audit officer. Report must be signed by company's authorized officer. Proper internal procedures must be into place to ensure it is prepared on a timely basis in accordance with the regulatory requirements and be made readily available for review by RMCD upon request. Additionally, 39 percent of manufacturers commented on the issues of tax complexity which linked to the problems faced by businesses in compliance, namely frequent changes of sales tax regulations, excessive details, too many computations as well as details of special records that have to be kept by businesses (Deloitte, 2019). Tax complexity would impact compliance behaviour among sales taxpayers. Most registered business owners faced the issues of clarity on the exemption procedures for sales tax. (Deloitte, 2019).

The lack of clarifications on the application for an exemption from sales tax is a significant technical matter and manufacturers applaud the Government's commitment to expand the Sales and Service Tax (SST) list to include non-taxable products in order to reduce rising business costs. This also provide local manufacturers and traders sell similar imported goods have equal playing conditions. From the recent internal survey carried out among 517 members from Federation of Malaysian Manufacturers (FMM) together with the Malaysian Institute of Economic Research (MIER) in March 2019, sales tax implementation has been experiencing challenges due to the lack of understanding of the new regime and uncertainty in the classification and treatment of taxable items (Ching, 2019). It was also indicated that the level of service quality provided by custom officers did not meet the needs and expectations of taxpayers, particularly in delivering accuracy and balancing customer expectations. Service quality can be considered as a factor contributing to taxpayers' compliance behaviors and can be perceived as the taxpayers' assessment of the level of effectiveness and efficiency of RMCD's tax administration.

Registered manufacturers must therefore be mindful of the late fines for non-compliance and avoiding the refund of net income tax to the RMCD. It is also essential to recognize the degree of knowledge of business operators and the problems they are likely to face with SST 2.0 implementation. RMCD may perform investigations or pursue civil proceedings against businesses in case of violation of the Sales Tax Act 2018 and other relevant laws or regulations. Registered manufacturers who operate as intermediaries ought to be educated on the sales tax and be cognizance that sales tax non-compliance will affect their business operations. Custom officers are allowed to contact any registered manufacturers to answer queries and for late business registration for sales tax. Custom rules and actions by custom officers in accordance to custom rules are extremely necessary to ensuring that individuals and potential taxpayers 
comply with tax regulations, such as adequately filing and sending tax returns, and paying tax on schedule. It also applies to RMCD's monitoring, recording, auditing and imposition of penalties on eligible taxpayers who refuse to register as licensee in local sales tax.

Depending on the taxable duration, registered manufacturers will file their sales tax returns (SST 02) every two months. Penalties can be levied if the offences are committed such as failure to file; omissions in the net tax payable, no SST refund is made, a sales tax report is released without payment or with a reduced payment. A late payment penalty ranging from 10 $\%$ to $40 \%$ of the amount not paid is usually enforced since the last 30-day minimum to a limit of 90-day duration (RMCD, 2018). In addition, compliance cost is an important factor in tax non-compliance. The Federation of Malaysian Manufacturers (FMM) has also been in consulting its members for recommendations to improve government policy and reduce the cost implications that will affect the competitiveness of Malaysia's supply chain. FMM noted that the sales tax raised business costs for of its members while the SST removed some of the financial and logistical pressures on producers and estimated that business costs for Malaysian manufacturers decreased by $10 \%$ (Ying, 2019). About $36 \%$ of respondents claimed that under the SST, the average cost for raw materials, goods and services was higher than during the GST period (Kana, 2019). This study investigates the issue of compliance level among SMEs taxpayers by examining the relationships between the factors influencing SME tax compliance behaviors in Malaysia namely tax complexity, tax fairness, peer influence, tax law enforcement, tax knowledge, service quality and compliance costs with sales tax compliance. Moreover, this analysis would shed some light in the perception of fairness of the sales tax system and uncover the degree of support and compliance from business associates by evaluating taxpayers' conduct. There is also a shortage of academic studies to explicitly examine the determinants of sales tax 2.0 compliance among SMEs in Malaysia. Identifying factors affecting taxpayers' compliance behaviour is critical in formulating initiatives to encourage taxpayers to participate in compliance activities over time.

\section{Literature Review}

\section{Definition of Sales Tax Compliance}

Sales tax compliance is defined as compliance with all procedures and regulations, including accurate reporting of actual sales tax paid and received, true sales tax liability, timely payment of all sales taxes and reporting of sales (Nura et al., 2017). Compliance with the sales tax can moreover be defined as a correct record of details in the sales invoice, instead of being fraudulent in the invoice to pay less sales tax. Business entities should have ability to submit accurate and complete sales tax returns in full satisfaction and conformity with all the regulations and sales tax laws of a tax authority (Ocheni, 2015). This present study employs the Fischer's model as underpinning theory to understand tax compliance behaviour of SMEs taxpayers. Fischer, Wartick, and Mark (1992) incorporated various factors into a single model where economic and socio psychological factors were integrated. Seven factors impacting compliance with sales tax are classified into two categories in this research, namely economic factors and non-economic factors. Economic factors are those variables that have an underlying impact on one's benefit, such as tax law enforcement being an economic cause that the taxpayer would be penalized if the non-compliant behaviours were found. The level of tax complexity, tax fairness, peer influence, tax knowledge, service quality and compliance cost are those behavioural considerations that come under category of non-economic variables. 


\section{Factors Affecting Sales Tax Compliance}

Tax complexity is characterized as the complexity of the tax system, the complexity of enforcement, the complexity of the rules and the complexity of the procedures (Saad, 2014). In this study, sales tax complexity is referred to as behavior relevant to the difficulties faced by companies with sales tax laws, including regular adjustments, onerous specifics, multiple estimates and descriptions of various business records. The more sophisticated the tax system, the lower the propensity of taxpayers to comply well with the filing of the correct tax returns as well as the collections and payments of taxes within the stipulated time frame. Hardika's (2006) and Salman's and Farid's (2010) work identified the nature of the tax code and HS code (Hard) as factors that affected compliance amongst taxpayers. Cuccia and Carnes (2001) found a negative cor-relationship between tax complexity and ability to adhere to tax payments while Abdul-Jabbar and Pope (2008) demonstrated increased tax complexities and frequent changes in tax laws had a negative effect on the performance of SMEs. Pope and Abdul-Jabbar (2008) claimed that tax complexity was always related to tax enforcement costs, rendering failure in compliance a simpler alternative option for most companies. Some recent research studies showed that sales tax compliance was negatively impacted by market complexity (Woodward $\&$ Tan, 2015). The more complex a tax code law, the lower the taxpayer's incentive to compliance exposed the link between understanding of the tax laws and compliance behaviour. This addition to the model will potentially contribute to the tax compliance literature because it investigates specific habits implicit in SME taxpayers.

Tax fairness refer to payment of sales tax (including its related fines) to tax authorities in a fair manner, whereby the incidental amount of which equals the recorded amount of sales tax. If people believe the tax system is equal, they will have a stronger tendency for compliance in the tax system, which will enable a person to show adherence to tax obligations. This study refers to tax fairness, such as sales tax distribution rates and sales tax penalty rates. Recent work had identified a positive correlation between tax fairness and tax compliance (Fochmann \& Kroll, 2015; McKerchar, Bloomquist \& Pope, 2013; Kirchler \& Wahl, 2010; Feld \& Frey, 2007). The literature also showed a positive relationship between tax fairness and sales tax compliance (Lin and Chin-Fatt, 2000; Adams \& Webley, 2001; Woodward \& Tan, 2015; Yahaya, 2015). Several studies also found no connection between tax fairness and tax compliance (Abdul Jabbar, Hijattulah, 2009). Some studies even suggested conflicting findings on the relationship between tax compliance and tax fairness (Sinnasamy, Perabavathi, Zainol Bidin, Syed Soffian Syed Ismail, 2015). In terms of sales tax, the three previous results revealed a positive correlation between tax fairness and compliance with sales tax (Woodward et al., 2015)

Peer influence is part of Fischer 's model beliefs and expectations. The term peers are generally defined as associates of taxpayers and they include relatives, friends, co-workers and colleagues (Jackson and Milliron, 1986). Peer groups have a potent effect on preferences, behaviour and personal values of taxpayers (Puspitasari and Meiranto, 2014). Hence, Lefebvre et al. (2015) reported the significance of not ignoring the presence of peer impact when examining the tax compliance behaviour. Chau and Leung (2009) stated that peers' influences are reflected in taxpayer's anticipations in relation to disapproval or approval of tax noncompliance, whereas Alm and McKee (1998) declared that social norms are a major determinant of tax compliance. The present study defines peer influence as the effect of people 
who are significant influences on SMEs' owner-managers in their sales tax compliance decisions, thus contributing in shaping their attitude towards sales tax compliance. In SMEs, peers have influences on tax obligation behaviour of their counterparts, and SMEs will evade tax payment if they felt that their peers have been evading even with punishment (Maseko, 2014; Omweri et al., 2010). Hence, a taxpayer is affected by the perception of his peer's behaviour. In contrast, if the taxpayers think of others as being honest, tax moral would rise (Frey and Torgler, 2007). However, the relationship between tax compliance and social norms is complex (Kirchler et al., 2008).

According to Kamil (2006), laws and its enforcement exist mainly to control and ensure societies fulfil their responsibilities by obeying the laws. In an effort to prevent tax evasion, traditionally, the government depends on criminal and civil penalties. Tax evasion still happens even though tax authorities increase the volume in auditing. Trivedi et al. (2005) found that as tax authorities increased their audit operations, tax declaration activities by taxpayers also increased correspondingly. In this study, enforcement of tax laws refers to inspection, tracking, auditing and penalties imposed by RMCD on manufacturers who fail to register and comply as law abiding sales tax taxpayers. Taxpayers who are found guilty are subject to fines by the authority. In regard to compliance behavior of sales tax implementation, the perception on tax laws and enforcements by RMCD is important.

According to Sales Tax Act 2018, those who fail to register in the system or evade tax payments are subject to penalties. Penalties may be imposed if the offences are committed for any deficiency on the net tax payable such as no sales tax return is made, or a sales tax return is submitted without payment or lesser payment. Taxpayers' perception on tax laws and enforcements is the main focus by examining their perceptions of benefits reaped by tax evasion and the incidental risks involved. Allingham and Sandmo (1972) noticed a positive association between legal attitudes and high enforcement and compliance behaviour. They used the economic criminal method to explain tax activities assuming that if tax evaders were quickly detected and large fines were levied, tax enforcement would improve. Murphy (2005) argues that the only method to minimise tax evasion is to enforce financial fines on tax evaders.

Tax knowledge relates to a method of reminding taxpayers about tax laws and other tax-related facts (Hasseldine et al., 2009). Financial awareness includes knowledge of tax regulations. Poor tax knowledge can lead to mistrust and negative compliance (Mukhlis et al., 2015). Tax knowledge would allow SMEs to comply with the tax laws and change their perceptions and attitudes. This will encourage SMEs to deal with their tax compliance problems and improve their view of tax compliance by developing a supportive atmosphere (Gitaru,2017). Tax knowledge affects taxpayers' grasp of knowledge in tax legislations and regulations to prevent tax non-compliance (Kasipillai, Aripin \& Amran, 2003). Improving tax knowledge of taxpayers would allow them to understand tax structures and tax laws in growing regions.

Loo, Mckerchar, and Hansford (2009) considered tax awareness as a significant element in evaluating taxpayer compliance behavior. Mohamad, Nor, Bakar and Nanta (2013) and Pui Yee, Moorthy and Choo Keng Soon (2017) believed tax knowledge is required to strengthen tax compliance discipline among taxpayers, which implies that tax knowledge has a positive relationship with tax compliance. Saad (2014) stressed the value of tax knowledge in 
preventing tax non-compliance. Studies indicated that taxpayers who have inadequate knowledge of the technical issues would believe that the tax structure is complex this would promote non-compliance. Mukasa (2011) confirmed that tax knowledge has a good, advantageous association with tax compliance and would contribute to lower levels of enforcement. According to Mukhlis, Utomo and Soesetio (2015), Indonesia has a clear and significant partnership the handicraft SME sector in fostering understanding of tax laws and regulations. Taxpayers with adequate tax knowledge can easily adopt their on-time tax obligations and submit tax return documents. Taxpayers are expected to file their absolute; and accurate tax returns provided they have sufficient tax comprehension.

Service is a form of helping (or preparing to support a person to fulfill all regulatory requirements). Meanwhile, tax controllers are government employees. Service tax authorities can be interpreted as tax officials responsible for assisting, overseeing, handling or preparing all related uses tax documentation for an individual who is a taxpayer in this case (Jatmio, 2006). Service quality concerns the perception whether people are satisfied or not with the services provided. Quality of services is a metric of service quality and reflects whether the services fulfill the customer's needs (Sapriadi, 2003). Customer service is a significant area of research and affects consumer sentiment. Service quality is defined as the difference between consumer perceptions of service prior to actual service delivery and their experience of service delivered (Parasuraman et al.,1988). Chen (2010) defined the service level as an attempt to satisfy customer expectations and desires to ensure continuity in meeting consumer preferences. Tax service efficiency can be described as standard assessment of taxpayer's tax administration. Many researchers have studied the concept of service quality as a framework for tax purposes (Connolly \& Bannister, 2008; Ali et al., 2017; Nurhayatiet et al., 2015; Jaya et al., 2017). Mustapha and Obid (2015) described service quality as a factor leading to taxpayers' compliance and it comprises assessing sensitivity, informativity, and reliability of service to taxpayers. Stinglingh (2014) sought to assess service efficiency from a tax practitioner 's viewpoint.

Compliance costs are identified as the mandatory costs that taxpayers incur in fulfilling their tax obligations (Eragbhe \& Modugu, 2014). Compliance costs of taxes are expenses incurred to enable taxpayers to satisfy their tax obligations beyond the tax owed, in addition to their tax liabilities, in fulfilling the criteria in tax laws (Rahmawati, 2012). For a business, it includes the expenses of collecting, submitting and paying taxes, as well as the costs of obtaining information which include details on its legal responsibilities and penalties, and the associated costs of proper housekeeping of relevant documents as required by tax authorities.

Eichfelder \& Vaillancourt (2014); Tran-Nam et al., (2000) describe three main components of compliance in which consist of taxpayers' income, time and psychological costs. Time costs are expended for handling tax information records, reviewing the tax forms or writing tax reports by tax practitioners, as well as time spent in dealing with tax officials. Psychological effects contribute impactfully on taxpayers facing tax problems, such as anxiety of grappling with complicated tax issues. The present study records all organizational time expended and financial expenses incurred but does not measure taxpayers' psychological costs. Xin, Khai, Fong and Chen (2015) study on the relationship between compliance costs, tax knowledge, tax agent and taxpayer's compliance behaviour found that compliance costs substantially and negatively associated with to compliance behaviour. Faridy et al., (2014) analysis on the 
connection between the sophistication of value added (VAT) legislations and compliance behaviour found that compliance expenses will not improve voluntary compliance habits of taxpayers. Furthermore, Nzioki and Peter (2014) analyzed the correlation between compliance costs and tax compliance, and their findings showed there was a significant negative correlation between compliance costs and tax compliance behaviour. There is sufficient proof to show that higher compliance costs will lead to taxpayers' failure to pay taxes (Xin et al., 2015; Faridy et al., 2014; Nzioki \& Peter, 2014)

\section{Method}

The population of the study comprises 3,100 registered SMEs with Federation of Malaysian Manufacturers (FMM Directory, 2018). This study will use a sample of sales tax registered companies located at Selangor state. Estimate 1,302 from total Malaysian SMEs registered business entities which represent majority portions of SMEs registration. The unit of analysis for this study is at individual level, whereby the individual taxpayers selected to participate in the present study will be from corporate organizations. They are SMEs manufacturer registered with the RMCD. To represent the demographic of manufacturers, annual sales turnover must exceed RM 500,000 and the head of management such as the chief executive officer, directors or senior finance manager were target respondents who will be approached to answer questions on sales tax compliance behaviour as they have reasonable knowledge about their businesses and has an appropriate capacity in their respective businesses. All employers in the manufacturing sector, $75 \%$ employers are from small and medium enterprises (SME) with employees less than 200 whilst $25 \%$ employers are from large employers with employees more than 200. The total selected population will be 977 (75\% from 1,302 registered SMEs companies from Selangor State). Krecjie and Morgan (1970) describe, for a population of 977 as in the present study, a sample size of 276 samples is adequate. In this present study, the data were collected through structured questionnaires with 5-point Likert scale ranging from $1=$ strongly disagree to $5=$ strongly agree. The simple random sampling technique is applied to assure equal chance participation from FMMs population. Techniques of data analysis applied in the present study are combinations of descriptive and inferential statistics. Thus, descriptive statistics will be computed through statistical package social Science (SPSS) version 23. There were 42 items will be constructed to measure the dimension of the research model, the responses and information collected from the survey will be tested such as descriptive statistics, reliability analysis, Pearson's Correlation Analysis and simple Multiple Regression Analysis. This study is associated with the Fischer's model (1992) where economic and sociopsychological factors are considered in determining tax compliance among SMEs. This study has identified seven independent variables namely tax complexity, tax fairness, peer influence, tax law enforcement, tax knowledge, service quality and compliance cost might have an association with SME's sales tax compliance behaviour under sales tax system as dependent variable.

Based on the literature reviewer, the following hypothesis were posited:

H1: There is a negative relationship between tax complexity and sales tax compliance behaviour H2: There is a positive relationship between tax fairness and sales tax compliance behaviour H3: There is a positive relationship between peer influence and sales tax compliance behaviour H4: There is positive relationship between tax law enforcement and sales tax compliance behaviour 
H5: There is a positive relationship between tax knowledge and sales tax compliance behaviour H6: There is a positive relationship between service quality and sales tax compliance behaviour

H7: There is a negative relationship between compliance cost and sales tax compliance behavior

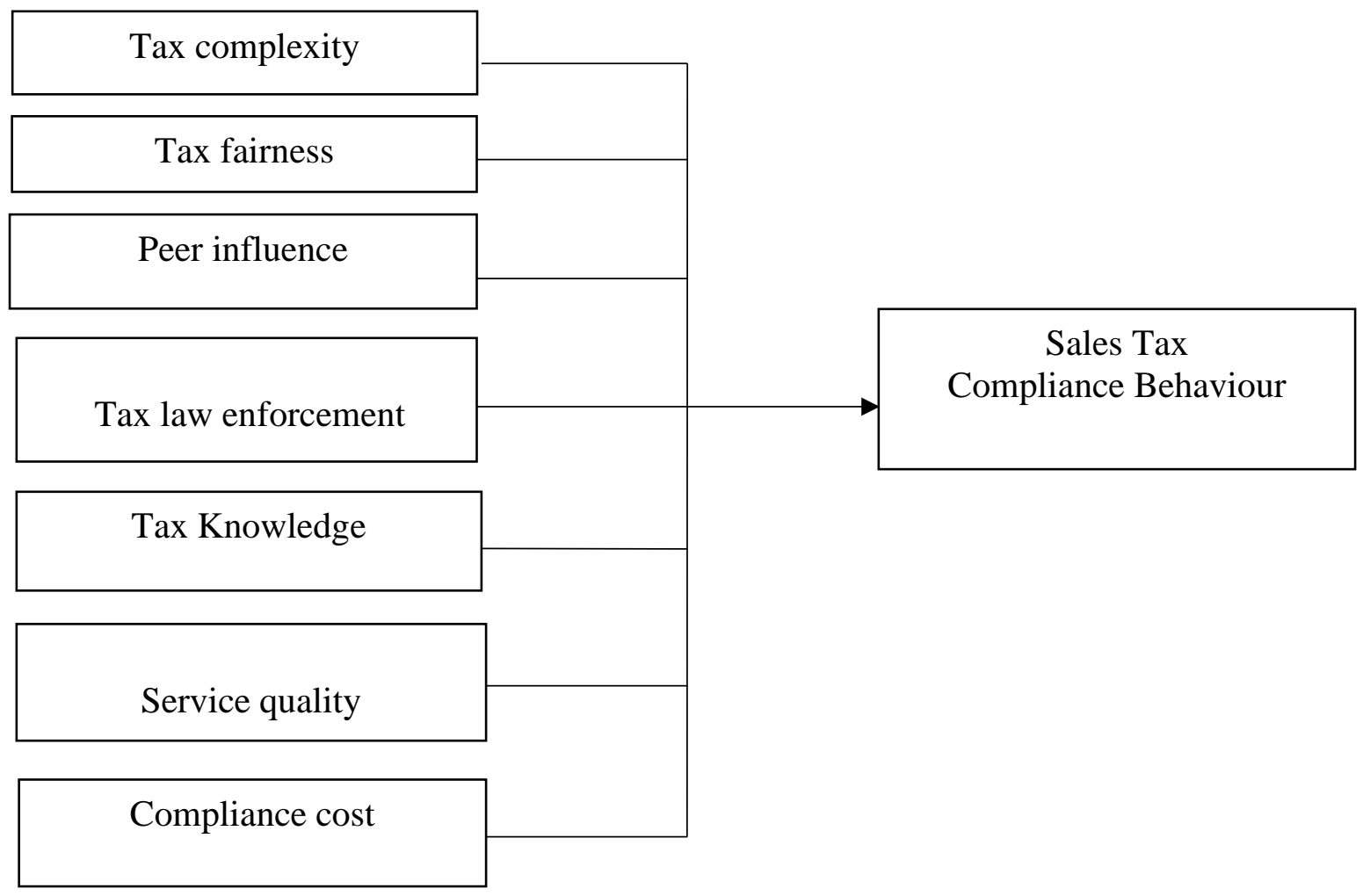

Figure 1: Conceptual Framework

\section{Results}

\section{Results of Reliability Test}

The reliability of the measurements used in this study was determined by evaluating the internal accuracy of the measuring items using Cronbach's alpha. Bland and Altman (1997) suggested that $\alpha$ from 0.7 to 0.8 be considered suitable for basic research, while a much higher $\alpha$ of 0.9 is needed for clinical use. Different research uses acceptable alpha values from 0.70 to 0.95 to ensure a scale 's internal accuracy (Tavakol \& Dennick, 2011). Table 2 indicates that all alpha values of Cronbach 's structures vary from 0.784 to 0.911 under which they are considered as acceptable and recommended. Specially, the Cronbach's alpha coefficient of peer influence are service quality are rated excellent (> 0.9); tax knowledge and compliance cost are rated good $(>0.8)$ while the coefficients of other latent variable (tax complexity, tax fairness, tax law and enforcement and sales tax compliance) are within the acceptable level ( $>0.70)$. Specifically, the Cronbach alpha coefficient of peer influence and service quality are rated excellent (>.90); tax complexity, tax fairness, tax knowledge and compliance cost are rated good (>.80) while the coefficients of other latent variables include sales tax compliance and tax law and enforcement are within the acceptable level (>.70). 
Volume 2 Issue 5 (December 2020) PP. 01-20

DOI 10.35631/AIJBAF.25001

Table 1: Reliability of Latent Variables

\begin{tabular}{lcc}
\hline & Items & Cronbach's Alpha \\
\hline Sales tax-compliance & 6 & 0.797 \\
Tax complexity & 5 & 0.828 \\
Tax fairness & 4 & 0.823 \\
Peer influence & 5 & 0.903 \\
Tax law and enforcement & 4 & 0.784 \\
Tax knowledge & 6 & 0.834 \\
Service quality & 5 & 0.911 \\
Compliance cost & 5 & 0.883 \\
\hline
\end{tabular}

\section{Correlation Analysis}

The correlation analysis conducted to determine whether there is a significant relationship between tax complexity, tax fairness, peer influence, tax law enforcement, tax knowledge, service quality, sales tax compliance, compliance cost behaviour. Table 2 presents the results of the matrix, four correlations at 0.01 are significant, the survey results indicate that four variables are strongly and significantly linked to sales tax compliance (STC) as their $r$ value is positive, and $\mathrm{P}$ values are all below 0.01. From Table 1, tax complexity ( $\mathrm{r}$-value $=0.379$, $\mathrm{P}<0.01)$, tax enforcement $(\mathrm{r}$-value $=0.323, \mathrm{P}<0.01)$, tax knowledge $(\mathrm{r}$-value $=0.435, \mathrm{P}<0.01)$ all have medium significant correlation with sales tax compliance as their $r$-value is more than 0.4 but less than 0.5. Peer influence ( $\mathrm{r}-\mathrm{value}=0.522, \mathrm{P}<0.01$ ) showed strong correlation with sales tax compliance. These findings suggest that company management can improve sales tax compliance by improving related independent peer influence variables. Peer influence as the effect of individual who are significant for business owners on their sales tax compliance. This refers to business partners, relatives, friends, colleagues and colleagues who can shape sales tax compliance attitudes. Correlation analysis can also be used to detect multicollinearity problem.

Table 2: Correlation Matrix of Latent Variables

\begin{tabular}{lcccccccc}
\hline & TC & TF & PI & TLE & TK & SQ & CC & STC \\
\hline TC & 1 & & & & & & & \\
TF & $0.451^{* *}$ & 1 & & & & & & \\
PI & $0.443^{* *}$ & $0.346^{* *}$ & 1 & & & & & \\
TLE & $0.380^{* *}$ & $0.415^{* *}$ & $0.564^{* *}$ & 1 & & & & \\
TK & $0.547^{* *}$ & $0.340^{* *}$ & $0.531^{* *}$ & $0.568^{* *}$ & 1 & & & \\
SQ & $0.408^{* *}$ & $0.469^{* *}$ & $0.258^{* *}$ & $0.425^{* *}$ & $0.356^{* *}$ & 1 & & \\
CC & 0.037 & 0.011 & $0.184^{*}$ & $0.304^{* *}$ & 0.127 & 0.080 & 1 & \\
STC & $0.379^{* *}$ & 0.085 & $0.522^{* *}$ & $0.323^{* *}$ & $0.435^{* *}$ & 0.085 & 0.145 & 1 \\
\hline
\end{tabular}

Note: $\mathrm{TC}=$ Tax complexity. $\mathrm{TF}=\mathrm{Tax}$ Fairness, $\mathrm{PI}=$ Peer influence, $\mathrm{TLE}=\mathrm{Tax}$ law and enforcement, TK=Tax knowledge, $\mathrm{SQ}=$ Service quality, $\mathrm{CC}=$ Compliance cost 
** Indicates correlation is significant at the 0.01 level (2-tailed).

* Indicates correlation is significant at the 0.05 level (2-tailed).

\section{Results of Factor Analysis}

In this research, factor analysis was performed using Principle Component (PCA) with varimax rotation on all objects. Measurement in this study is Kaiser-Meyer Olkin (KMO) and Barlett Sphericity Measure (BTOS). KMO is used to investigate suitability samples and BTOS to determine suitability of factor analysis (Hair et al., 1998). In general, the results of the EFA were assessed by the rule of thumb provided by Hair et al. (2010) and Coakes and Ong (2011). They argued that KMO should be $>0.60$, Bartlett's Test of Sphericity should be significant at $\mathrm{P}<0.05$, communality $>0.50$, and factor loading $>0.40$, eigenvalue $>1$ or total variance explained of at least $60 \%$ and anti-image correlation coefficient $>0.50$. Furthermore, Williams, Brown and Onsman (2012) pointed out that KMO with 0.50 is considered acceptable for factor analysis.

In this study, a factor analysis was run to verify the postulated dimension of the independent variables (the seven factors contributing to sales tax compliance) and dependent variables. Factor analysis was conducted to confirm the variables of tax complexity, tax fairness, peer influence, tax law enforcement, tax knowledge, service quality, compliance cost and sales tax compliance were a different construct. The Kaiser-Meyer-Olkin (KMO) values after the exploratory factor analysis (EFA) for tax complexity, tax fairness, peer influence, tax law enforcement, tax knowledge, service quality, compliance cost and sales tax compliance behavior were $0.792,0.789,0.778,0.777,0.8030 .851,0.857$ and 0.830 respectively.

Table 3: Factor Analysis

\begin{tabular}{lcccc}
\hline \multicolumn{1}{c}{ Construct } & $\begin{array}{c}\text { Number of } \\
\text { items }\end{array}$ & $\begin{array}{c}\text { Number of } \\
\text { factor }\end{array}$ & KMO & $\begin{array}{c}\text { Total variance } \\
\text { explained }\end{array}$ \\
\hline Tax complexity & 5 & 1 & 0.792 & 67.36 \\
Tax fairness & 4 & 1 & 0.789 & 66.09 \\
Peer influence & 5 & 1 & 0.778 & 72.56 \\
Tax law enforcement & 4 & 1 & 0.777 & 61.55 \\
Tax knowledge & 6 & 1 & 0.803 & 55.58 \\
Service quality & 5 & 1 & 0.851 & 73.93 \\
Compliance cost & 5 & 1 & 0.857 & 68.32 \\
Sales tax compliance & 6 & 1 & 0.830 & 52.39 \\
\hline
\end{tabular}

\section{Multiple Regression Results}

The multiple regression analysis (entered method) is applied to measure the variables that explained the variance in the overall sales tax compliance. Table 4 below shows the results of multiple regression analysis of the research. The statistical analyses revealed that model was statistically significant as indicated by the $\mathrm{F}$ value of $11.294(\mathrm{P}=.000)$ respectively. This suggests that this model have a significant ability to predict sales taxpayers' behaviour in Malaysia. This represents approximately a 59.8\% increase over the account of tax compliance behaviour offered by this model. With regards to the independent variable, tax complexity $(\beta=.258 ; \mathrm{P}=0.018)$, peer influence $(\beta=.343 ; \mathrm{P}=0.00)$ and tax knowledge $(\beta=.170 ; \mathrm{P}=0.043)$ were found significantly relate to sales tax compliance behaviour positively. Meanwhile, tax fairness $(\beta=-.169 ; \mathrm{P}=0.041)$ was negatively relate to sales tax compliance behaviour. 
Volume 2 Issue 5 (December 2020) PP. 01-20

DOI 10.35631/AIJBAF.25001

Table 4: Moderate Multiple Regression Test Results

\begin{tabular}{|c|c|c|c|c|c|}
\hline & \multicolumn{2}{|c|}{$\begin{array}{l}\text { Unstandardized } \\
\text { Coefficients }\end{array}$} & \multirow{2}{*}{$\begin{array}{c}\text { Standardized } \\
\text { Coefficient } \\
\text { Beta }\end{array}$} & \multirow{2}{*}{$\mathbf{T}$} & \multirow{2}{*}{ Sig } \\
\hline & B & Std Error & & & \\
\hline (Constant) & 14.827 & 1.778 & & 8.337 & .000 \\
\hline Tax complexity & .258 & .108 & .211 & 2.393 & $.018 * *$ \\
\hline Tax fairness & -.169 & .082 & -.171 & -2.061 & $.041 * *$ \\
\hline Peer influence & .343 & .076 & .400 & 4.544 & $.000 *$ \\
\hline $\begin{array}{ll}\text { Tax law and } \\
\text { enforcement }\end{array}$ & .011 & .117 & .009 & 0.091 & .928 \\
\hline Tax knowledge & .170 & .083 & .190 & 2.040 & $.043 * *$ \\
\hline Service quality & .-.087 & .072 & -.099 & -1.217 & .226 \\
\hline Cost Compliance & .042 & .065 & .046 & .647 & .518 \\
\hline
\end{tabular}

*Statistically significant at $1 \%$ level

**Statistically significant at $5 \%$ level

\section{Discussion and Conclusion}

This study aims to investigate sales tax compliance and its determinants. In this study, taxpayers are the respondents who claimed initially that the challenge of sales tax for they have submitted a valid sales tax return due to longer time period taken to file sales tax returns, which include tax planning and time taken to obtain advices from tax authorities (Gambo, Mas'ud, Nasidi \& Oyewole, 2014). Gradually, some respondents have claimed that they have confidence level to complete sales tax appropriately and accurately. Therefore, it conclude that tax complexity is influential for tax compliance of sales tax, small and medium-sized businesses considered that tax complexity may have an impact on their level of compliance as they were aware of the final outcome of not dealing with the sales tax laws and regulations will subject to penalties.

Tax fairness affects sales tax compliance as SMEs consider that compliance with sales tax is the sales tax system's fairness. To improve sales tax compliance, this work indicates that the tax authority should set the fair registration threshold and minimize the cost of business compliance with sales tax. The study also provided evidence that there was a relationship between perceived tax fairness and sales tax compliance behaviour. This result indicated that perceptions of SMEs on tax fairness might have a positive impact on their sales tax compliance behaviour. The findings of this study may provide policymakers and tax authorities with information when developing policies not only for tax compliance.

Peer influence plays a significant role in influencing one 's actions to comply with sales tax. Referential classes, such as business partners have been found to have a positive effect on taxpayers when dealing with sales tax. This study found that there is a significant positive relationship between peer influence and compliance with sales tax among small and mediumsized taxpayers. This research has demonstrated that business partners control taxpayers' 
decisions in tax declarations. Business partners as delegates of taxpayers and RMCD, define the actions of taxpayers in terms of tax compliance. For this analysis, taxpayers are the impact of business partners on the declaration and reporting of sales tax income specifically by compliance with the sales tax laws. In general, the finding is consistent with previous research that showed a substantial impact of the subjective standard on behavioral intention (Chu \& Wu, 2004; Taylor \& Todd, 1995: Zainol et al., 2009).

This study revealed statistically significant compliance between tax knowledge and sales tax compliance among SMEs in Malaysia. This result suggested that a higher level of tax knowledge could improve sales tax compliance. It is consistent with earlier studies that sufficient knowledge is used to minimize sales tax non-compliance (McKerchar, 1995; Palil \& Mustapha, 2011). Tax knowledge involves sales tax rules and rules. Furthermore, tax knowledge is one of the key considerations of voluntary tax compliance. It plays a major role in shaping sales tax behavior (MR Palil, MR Akir, W Ahmad, 2013). Most previous literature found that higher tax knowledge would lead to higher tax compliance, as Nzioki and Peter (2014), Loo, Mckerchar, and Hansford (2009) strongly support this finding. Mukhlis, Soesetio (2015) and Mukasa (2008). Taxpayers use tax knowledge especially on tax law, to find solutions to tax compliance in the tax system. Since SME taxpayers have the necessary and specific knowledge in the area of sales tax, they continue to comply with the applicable sales tax regulations and laws. Hence, adequate sales tax knowledge induced to tax compliance among taxpayers. It is suggested that manufacturing owners should attend the courses and seminars conducted by RMCD by improving sales tax knowledge. Taxpayers who have ample tax knowledge are in a position to accurately view their tax liabilities and to file their tax return forms on time. They are expected to submit a complete, correct tax return precisely if they have sufficient knowledge to understand the tax system. Overall, it can conclude that increasing tax compliance is to enhance taxpayer's tax knowledge.

In the present research, a model is proposed to provide insight into the sales tax compliance of Malaysian SMEs. The model is an extension of the Fischer model, with the consideration of the relationships of socio-psychological factors (tax complexity, peer influence, tax fairness, tax knowledge, service quality and compliance cost) and economic factors (tax complexity) with sales tax compliance. This study contributes significant input to the government, tax agencies and the public economic policies by providing insights into relationship between sales tax and compliance behaviour. It is also expected to contribute empirical evidences in the evidence of compliance behaviour of SMEs taxpayers, by providing valuable information to SMEs owner-managers to improve sales tax compliance in the future. It provides crucial information concerning the impact of factors on the Malaysian sales tax compliance that could be used to formulate social, economic and political policies, such as enable the government to be more realistic in designing strategy policy on tax compliance bahaviour in Malaysia. In summary, the current study provides several contributions, particularly to the theory, methodology and practice, and offers explanations on the way of how tax compliance can be enhanced.

The results and identified limitations of this study provide insight into potential lucrative areas of tax compliance that may need future researchers ' attention, especially in Malaysia. Furthermore, future research may want to consider extending tax compliance studies to nonSelangor areas, where there is a large disparity in development between Selangor and non- 
Selangor areas. The current study model was capable to explain 32.6 percent of the total variance in sales tax compliance, which means that there are other variables that could also significantly explain the variance in sales tax compliance. In other words, the remaining 67.4 percent of the variance in sales tax compliance could be explained by other variables. This study is considered the beginning of research in sales tax version 2.0 in Malaysia, the findings of this study suggest that the further extension of the tax compliance model, particularly Fischer's model to consider other possible contracts that could impact the sales tax compliance such government quality, tax audit, tax penalty, tax rate, tax moral, probability of detection, ethnic diversity as well as the moderating effect would further strengthen the predictive capacity of the model for better understanding taxpayers' compliance behaviour. In addition, research efforts could also concentrate on recognizing certain economic, social, psychological and cultural variables that can affect compliance behaviors of taxpayers, especially in developing countries. This opinion is focus on observations in the literature that tax enforcement activity is still mostly underdeveloped work (Andreoni, et al 1998; Chau \& Leung, 2009). Similarly, given findings in this analysis and other similar studies (Murphy, 2007; Wenzel, 2004 \& 2005), which endorse Kirchler et al. (2007)'s hypothesis that the interaction between tax compliance and its determinants could be moderated by certain variables, researchers may recognize the potential moderating impact of some financial, psychological or cultural factors on the relationship between tax compliance and its determinants. Such investigations would provide further information on taxpayers' behavior to better understand their compliance decisions.

Future research should exploit opportunities to conduct more sales tax compliance research using mixed methods of both qualitative and quantitative research. Mixed methodology strategy helps researchers to reduce respondents' psychological prejudice (Creswell, 2009). Researchers are also urged to follow open-ended questions in order to from the views of the respondents. Open-ended questions will help rich qualitative evidence and can offer ways for participants to learn about respondents. Future researcher should adopt longitudinal-sectional study. Researchers may assess variables over time in quantitative studies. Furthermore, more knowledge may be generated because it offers qualitative and quantitative details

To sum up, the present study has found that Fischer model can be applied in an indirect tax environment. This study can be considered a first that was conducted in the context of sales tax version 2.0 in Malaysia, the current study was designed to fill the gap in sales tax compliance literature. The study explores the factors contributing sales tax compliance and this study calls for future studies in the area of sales tax compliance of SMEs in order to better understand its determinants. The finding has verified that tax complexity, tax fairness, peer influence tax knowledge is significantly correlated with sales tax compliance. However, tax law and enforcement, service quality and compliance cost were not being remarkable to have an impact on sales tax compliance. This complex relationship is as advanced in the extended Fischer's tax compliance model.

This study has significant inputs to the government, tax agencies and public economic policy makers by providing insights into factors affecting sales tax compliance behaviour. It is provided empirical in the evidence on sales tax compliance behaviour of SMEs taxpayers and also provided valuable information to SMEs owner-managers to improve sales tax compliance in the future. It provides crucial information concerning the impact of factors affecting the 
Malaysian sales tax compliance that could be used to formulate social, economic and political policies as well as enable the government to be more realistic in designing strategies and policies on tax compliance bahaviour in Malaysia. In summary, the current study provides several contributions, particularly to theory, methodology and practice as well as offering explanations on the way on how tax compliance can be enhanced.

\section{References}

Abdul-Jabbar, H., \& Pope, J. (2008). The effects of the self-assessment system on the tax compliance costs of small and medium enterprises in Malaysia. Journals in Business \& Management, 23, 289-307.

Abdul-Jabbar, Hijattulah. Income tax non-compliance of small and medium enterprises in Malaysia: Determinants and tax compliance costs. Unpublished Doctorial thesis, Curtin University, 2009

Akinboade, O.A., 2015. Correlates of tax compliance of small and medium size businesses in Cameroon. Managing Global Transitions, 13(4): 389-413.

Alabede, J. O., \& Zainal Affrin, Z. (2011). Tax service quality and compliance behaviour in Nigeria: Do taxpayers financial condition and risk preference play any moderating role?. European Journal of Economics, Finance and Administrative Sciences, 35, 90108

Ali, M. M., Cecil, H. W., \& Knoblett, J. A. (2001). The effects of tax rates and enforcement policies on taxpayer compliance: A study of self-employed taxpayers. Atlantic economic journal, 29(2), 186-202.

Ali, M., Asmi, F., Rahman, M. M., Malik, N., \& Ahmad, M. S. (2017, September). Evaluation of E-Service Quality through Customer Satisfaction( A Case Study of FBR E Taxation). Open Journal of Social Sciences, 5, pp 175-195.

Allingham, M., \& Sandmo, A. (1972). Income tax evasion: A theoretical analysis. Journal of Public Economics, 1(3-4), 323-338.

Alm, J. (2012). Measuring, explaining, and controlling tax evasion: lessons from theory, experiments, and field studies. International Tax and Public Finance, 19(1), 54-77.

Alm, J., \& Mckee, M. (2006). Audit certainty, audit productivity, and taxpayer compliance. Andrew Young School of Policy Studies Research, 59(4), 06-43.

Alm, J., Clark, J., \& Leibel, K. (2016). Enforcement, socioeconomic diversity, and tax filing compliance in the United States. Southern Economic Journal, 82(3), 725-747.

Alshirah, A. F., Abdul-Jabbar, H., \& Samsudin, R. S. (2016). Determinants of sales tax compliance in small and medium enterprises in Jordan: A call for empirical research. World Journal of Management and Behavioral Studies, 4(1), 41-46.

Alshira ${ }^{e c h}$, A. F., Abdul-Jabbar, H., \& Samsudin, R. S. (2018). Sales tax compliance model for the Jordanian Small and medium enterprises research. Journal of Advanced Research in Social and Behavioural Sciences, 10(2), 115-130.

Al-Smirat, B. Y. (2013). The use of accounting information by small and medium enterprises in South District of Jordan (An empirical study). Research Journal of Finance and Accounting, 4(6), 169-175.

Al-Ttaffi, L. H. A., \& Abdul-Jabbar, H. (2015). A conceptual framework for tax noncompliance studies in a Muslim country: A proposed framework for the case of Yemen. International Postgraduate Business Journal, 7(2), 1-16 
Al-Ttaffi, L, \& Abdul-Jabbar, H. (2016). Service quality and income tax non-compliance among small and medium enterprises in Yemen. Journal of Advanced Research in Business and Management Studies, 4(1), 12-21.

Al-Zoubi, A., Khatatba, H., Salama, R. B., \& Khatataba, M. (2013). Methods of tax avoidance and evasion: The incapability of the Jordanian income tax law to face tax avoidance and evasion. Journal Almanara, 19(4),9-36.

Adams, C., \& Webley, P. (2001). Small business owners attitudes on VAT compliance in the UK. Journal of Economic Psychology, 22(1), 195-21

Andreas, \& Savitri, E. (2015). The effect of tax socialization, tax knowledge, expediency of tax id number and service quality on taxpayers compliance with taxpayers awareness as mediating variables. Procedia - Socialand Behavioral Sciences, 211(9), 163-169.

Ariel, B. (2012). Deterrence and moral persuasion effects on corporate tax compliance: Findings from a randomized controlled trial. Criminology, 50(1), 27-69.

Atawodi, O.W. and S.A. Ojeka, 2012. Factors that affect tax compliance among small and medium enterprises (SMEs) in North Central Nigeria. International Journal of Business and Management, Working, pp: 84-2.7(12): 87-97

Azmi, A., Sapiei, N. S., Mustapha, M. Z., \& Abdullah, M. (2016). SMEs' tax compliance costs and IT adoption: The case of a value-added tax. International Journal of Accounting Information Systems, 23, 1-13

Belay, S. A., \& Viswanasham, P. (2016). An assessment of business income taxpayers' tax knowledge, tax complexity, and tax compliance: A case of Amhara regional state of Ethiopia. International Journal of Science and Research, 5(5), 628-634.

Boonyarat, N., Sofian, S., \& Wadeecharoen, W. (2015). The antecedents of taxpayers ${ }^{\text {ce }}$ compliance behavior andthe effectiveness of Thai local government levied tax. International Business Management, 9(2), 182-190.

Chan, C. W., Troutman, C. S., \& Bryan, D. (2000). An expanded model of taxpayer compliance: Empirical evidence from the United States and Hong Kong. Journal of International Accounting, Auditing and Taxation, 9(2), 83-103.

Chau, G., \& Leung, P. (2009). A critical review of Fischer tax compliance model: research synthesis. Journal of Accounting and Taxation, 1(2), 34-40.

Chen, C. W. (2010, July 1). Impact of Quality Antecedents on Taxayer Satisfaction with Online Tax- filing Systems- An Empirical Study". Information and management, 47, pp.308315.

Connoly, R., \& Bannister, F. (2008). E- Tax Filing \& Service Quality: The Case of the Revenue Online Service. International Journal of Economics and Management Engineering, 2(2), pp.56-60.

Deloitte issue 3 , 2019 March Retrieved from https://www2.deloitte.com/content/dam/Deloitte/my/Documents/tax/my-tax-indirecttax-chat-mar2019.pdf

Eichfelder, S., \& Vaillancourt, F. (2014). Tax compliance costs: A review of cost burdens and cost structures. Review of Public Economics, 210(3), 111-148.

Eragbhe, E., \& Modugu, K. P. (2014). Tax compliance costs of small and medium scale enterprises in Nigeria. International Journal of Accounting and Taxation, 2(1), 63-87

Faridy, N., Copp, R., Freudenberg, B., \& Sarker, T. (2014). Complexity, compliance costs and non compliance with VAT by small and medium enterprises in Bangladesh: Is there a relationship. Australian Tax Forum, 29, 281-329. 
Faridy, N., Freudenberg, B., Sarker, T., \& Copp, R. (2016). The hidden compliance cost of VAT: An exploration of psychological and corruption costs of VAT in a developing country. eJournal of Tax Research, 14(1), 166-205.

Fadzilah, E. N., Mustafa, R. M., \& Putri, N. K. (2017). The effect of tax understanding, tax payness consciousness, quality of tax service, and tax sanctions on compulsory tax of SMEs in Banyumas Regency. Acta Univeresitatis Danubius. 13(4), 28-38.

Feld, L. P., \& Larsen, C. (2012). Self-perceptions, government policies and tax compliance in Germany. International Tax and Public Finance, 19(1), 78-103.

Fischer, C.M., Wartick, M., \& Mark, M. (1992). Detection probability and taxpayer compliance: A review of the literature. Journal of Accounting Literature, 11(2), 1-25.

Frey, B. (2003). Deterrence and tax morale in the European Union. European Review, 11(3), 385-406.

Frey, B., \& Torgler, B. (2007). Taxation and conditional cooperation. Journal of Comparative Economics, 35, 136-159.

Gambo, E. J., Mas'ud, A., Nasidi, M., \& Oyewole, O. S. (2014). Tax complexity and tax compliance in African self-assessment environment. International Journal of Management Research \& Review, 4(5), 575-582.

Giesecke, J., \& Tran, N. H. (2012). A general framework for measuring VAT compliance rates. Applied Economics, 44(15), 1867-1889.

Gitaru, K. (2017). The Effect of Taxpayer Education on Tax Compliance in Kenya. University of Nairobi, School of Economics. Kenya: Munich Personal RePEc Archive.

Hanefah, H. (1996). An evaluation of the malaysian tax administrative system and tax payers' perceptions towards assessment systems, tax law fairness, and tax law complexity (Unpublished doctoral thesis, Universiti Utara Malaysia)

Jackson, B. R., \& Milliron, C. V. (1986). Tax compliance research: Findings, problems and prospects. Journal of Accounting Literature, 5, 125-165.

Jaya, A. (2017, August). "Analysis of Effect of Knowledge and Service Quality, Accessibility of Information, Awareness and Behavior of Taxpayers and Impact on Satisfaction and Compliance With Taxpayers of Land and Buildings in The City Batam Island Riau Province". International Journal of Business and Management Invention, 6(8), pp.7383

Kamleitner, B., C. Korunka and E. Kirchler, 2012. Tax compliance of small business owners. International Journal of Entrepreneurial Behaviour and Research, 18(3): 330-351.

Kasipillai, J., Aripin, N., \& Amran, N. A. (2003). The influence of education on tax avoidance and tax evasion. eJournal of Tax Research, 1(2), 134-146.

Kasipillai, J. \& Jabbar, A.H. (2013). Tax compliance attitude and behaviour: Gender \& ethnicity differences of Malaysian taxpayers. The Malaysian Accountant, 7, 1-7.

Kirchler, E., Hoelzl, E., \& Wahl, I. (2008). Enforced versus voluntary tax compliance: The "slippery slope" framework. Journal of Economic Psychology, 29(2), 210-225.

Kirchler, E., Kogler, C., \& Muehlbacher, S. (2014). Cooperative tax compliance: From deterrence to deference.Current Directions in Psychological Science, 23(2), 87-92.

Lefebvre, M., Pestieau, P., Riedl, A., \& Claire, M. (2015). Tax evasion and social information: An experiment in Belgium, France, and the Netherlands. International Tax and Public Finance, 22(3), 401-425. https://doi.org/10.1007/s10797-014-9318-z

Loo, E.C., McKerchar, M., \& Hansford, A. (2008). Tax compliance behavior: Findings derived from a mixed method design. Paper presented at the 8th International Tax Administration Conference, Sydney. 
Loo, E., Mckerchar, M., \& Hansford, A. (2009). Understanding the compliance behaviour of Malaysian individual taxpayers using a mixed method approach. Journal of the Australiasian Tax Teachers Association, 4(1), 181-202.

Lutfi, A. A., Idris, K., \& Mohamad, R. (2017). AIS usage factors and impact among Jordanian SMEs: The moderating effect of environmental uncertainty. Journal of Advanced Research in Business and Management Studies, 6(1), 24-38.

Madanchian, M., Hussein, N., Noordin, F., \& Taherdoost, H. (2015). The role of SMEs in economic development: Case study of Malaysia. International Journal of Academic Research in Management, 4(3), 77-84

Maseko, N. (2014). The impact of personal tax knowledge and compliance costs on tax compliance behaviour of SMEs in Zimbabwe. Elite Research Journal of Accounting and Business Management, 2(3), 26-37.

McKerchar, M., Bloomquist, K., \& Pope, J. (2013). Indicators of tax morale: An exploratory study. eJournal of Tax Research, 11(1), 5-22.

Mohdali, R., Isa, K., \& Yusoff, S. H. (2014). The impact of threat of punishment on tax compliance and non-compliance attitudes in Malaysia. Procedia - Social and Behavioral Sciences, 164, 291-297.

Muche, B. (2014). Determinants of tax payer's voluntary compliance with taxation in east Gojjam-Ethiopia. Research Journal of Economics \& Businrss Studies, 3(9), 41-50.

Mukhlis, I., Utomo, S. H., \& Soesetio, Y. (2015, September !5). The Role of Taxation Education on Taxation Knowledge and Its Effect on Tax Fairness as well as Tax Compliance on Handicraft SME Sector in Indonesia". International Journal of Financial Research, 6(4), pp.161-169.

Murphy, K. (2007). Procedural justice and the regulation of tax compliance behaviour:The moderating role of personal norm. Andrew Young School of Policy Studies international conference. Atlanta: Georgia State University.

Mustapha, B., \& Obid, S. N. B. S. (2015). Tax service quality: The mediating effect of perceived ease of use of the online tax system. Procedia-Social and Behavioral Sciences, 172, 2-9.

Nzioki, P. M., \& Peter, O. R. (2014). Analysis of factors affecting tax compliance in real estate sector: A case of real estate owners in Nakuru town, Kenya. Research Journal of Finance and Accounting, 5(11).

Nura, M., Abdul-Jabbar, H. \& Ibrahim, I. (2017). VAT compliance and the influence of political and business environment: A proposed framework for Nigerian SMEs. Asian Journal of Business Management Studies, 8(2), 13-20.

Nurhayati, N., Halimatusadiah, E., \& Diamonalisa. (2015). "Influence of Tax Officer Service Quality and Knowledge of tax on Individual Taxpayer Compliance in Tax Office Bojonagara Bandung". International Journal of Applied Research, 1(8), pp. 805-809.

Ocheni, S. (2015). A causality analysis between tax compliance behaviour and Nigerian economic growth. Mediterranean Journal of Social Sciences, 6(1 S1), 577.

Omweri, L., Miqwi, W., \& Obara, M. (2010). Taxpayers attitudes and tax compliance behaviour in kenya how the taxpayers ' attitudes influence compliance behaviour among smes business income earners in Kerugoya. African Journal of Business \& Management, 1(8), 112-122.

Palil, M. R. (2010). Tax Knowledge and Tax Compliance Determinants in Self Assessment System in Malaysia. Malaysia: University of Birmigham. Management, 5(33), pp.12864-12872 
Palil, M. R., Zain, N. H. M., \& Faizal, S. M. (2012). Political affiliation and tax compliance in Malaysia.Humanities and Social Sciences Review, 1(4), 395-402.

Parasuraman, A., Zeithml, V. A., \& Berry, L. L. (1988). SERVQUAL: A Multiple Item Scale For Measuring Consumer Perceptions of Service Quality. Journal of Retailing, 64(1), pp. $12-40$.

Pope, J., \& Abdul-Jabbar, H. (2008). Small and medium-sized enterprises and tax compliance burden in Malaysia: Issues and challenges for tax administration. Small Enterprise Research, 16(1), 47-60.

Puspitasari, E., \& Meiranto, W. (2014). Motivational postures in tax compliance decisions: an experimental study. International Journal of Business, Economics and Law, 5(1), 100110.

Royal Malaysian Customs Department, Annual Report 2016

Royal Malaysian Customs Department, Sales tax Act 2018. Retrieved from https://mysst.customs.gov.my/SST Act

Royal Malaysian Customs Department. Guide on manufacturers- import and export. Retrieved from https://mysst.customs.gov.my/IndustryGuides

Royal Malaysian Customs Department. Guide on sales tax exemption under schedule $C$ Retrieved from https://mysst.customs.gov.my/IndustryGuides

Saad, N. (2012). Tax non-compliance behaviour: Taxpayers view. Procedia-Social and Behavioral Sciences, 65, 344-351.

Saad, N. (2014). Tax knowledge, tax complexity and tax compliance: Taxpayers' view. Procedia-Social and Behavioral Sciences, 109, 1069-1075.

Sapiei, N., Kasipillai, J. and Eze, U. (2014). Determinants of tax compliance behaviour of corporate taxpayers in Malaysia. eJournal of Tax Research, 12(2), pp.383-409.

Sapriadi, Doni (2013). Effect quality tax service, tax and awareness sactions against tapayers taxpayer compliance in the UN pay (in the District Selupu Rejang), Padang State University

Sinnasamy, P., Bidin, Z., \& Syed-Ismail, S. S. (2015). A proposed model of non-compliance behaviour on excise duty: A moderating effects of tax agents. Procedia - Social and Behavioral Sciences, 2011, 299-305.

Slemrod, J., 2004. Small Business and the Tax of small and medium size businesses in H.J. Aaron and J. Slemrod (eds), The Crisis in Tax Administration, Brookings Institution Press, Washington, D.C, pp: 69-123

Slemrod, J., Blumenthal, M., \& Christian, C. (2001). Taxpayer response to an increased probability of audit: Results from a controlled experiement in Minnesota. Journal of Public Economics, 79, 455-483.

Stinglingh, M. (2014). Service Quality Framework for the South African Revenue Service from the Perspective of the Tax Practitioner. Public Relations Review, 40, pp.240-250.

Tran-Nam, B., Evans, C., \& Walpole, M. (2000). Tax Compliance Costs: Research Methodology and Empirical Evidence from Australia. National Tax Journal, 53(2), 229-252.

Trivedi, V. U., Shehata, M., \& Mestelman, S. (2005). Attitudes, Incentives, and Tax Compliance. Canadian Tax Journal.

Wade, S. (2014). Compliance and non compliance behavior of business profit taxpayers ${ }^{\text {ee }}$ towards the tax system: A case study of Mekelle city. Scholars Journal of Economics, Business and Management, 1(10), 525-531. 
Webley, Paul, Caroline Adams, and Henk Elffers. Value added tax compliance. Paper Presented at the Conference 'Behavioral Public Finance: Towards a new agenda', University of Michigan Business School, April, 23- 24, 2004.

William, M. (2015). The influence of social norms and tax system on tax compliance. a case study of small and medium taxpayers in Tanga City- Tanzania (Unpublished doctoral thesis, University of Tanzania)

Woodward, L., \& Tan, L. M. (2015). Small business owners attitudes toward GST compliance: A preliminary study. Australian Tax Forum, 30(2), 517-550.

Xin, M. K. H., Khai, K. G., Fong, L. S., \& Chen, N. H. (2015). Factors affecting individual taxpayers' compliance in Malaysian tax filing system. The International Journal of Business \&Management, 3(9), 339-347. 